\title{
Impact of upstream industrial effluents on irrigation water quality, soils and plant in Alakia Area of Ibadan
}

\section{*11ERUOLA, AO; ${ }^{2}$ AWOMESO, JA; ${ }^{3}$ ERUOLA, AO; ${ }^{4}$ MAKINDE, AA; ${ }^{5}$ AYOOLA, KO}

\author{
${ }^{I}$ Department of Water Resources Management and Agrometeorology, University of Agriculture, Abeokuta, Nigeria \\ ${ }^{2}$ Department of Chemical Sciences, Yaba College of Technology, Lagos, Nigeria \\ *Corresponding Author E-mail: layosky@yahoo.com,08057354226
}

\begin{abstract}
Knowledge of irrigation water quality is critical to predicting, managing and reducing salt affect on soils. The study assessed the effect of industrial effluents on irrigation water quality, soils and plant tissues in Ibadan, Southwest Nigeria. The degree of pollution was evaluated using Sodium adsorption ratio, $\mathrm{pH}$, cations $-\mathrm{Cl}$ and $\mathrm{NO}_{3}$ and 4 heavy metals including $\mathrm{Pb}, \mathrm{Cu}, \mathrm{Cd}$ and $\mathrm{Zn}$ using standard procedures. The study established the presence of High $\mathrm{pH}(\mathrm{pH}=6.65)$ that caused high alkalinity leading to high SAR of 11.1 which is as a result of calcium and magnesium ions forming insoluble minerals leaving sodium as the dominant ion in solution. Presence of heavy metals in concentration higher than the recommended limits in irrigation water samples analyzed with $\mathrm{Cd}(0.05 \mathrm{ppm}), \mathrm{Cu}(0.3 \mathrm{ppm})$, $\mathrm{Pb}(0.03 \mathrm{ppm})$ and $\mathrm{Zn}(4.0 \mathrm{ppm})$ in the study location. It was concluded that Eleshin stream and the surrounding ground water is fit for irrigation in relation to sodium hazard, although it is acidic, thus enhancing leaching and corrosive tendencies of the irrigation water. High level of heavy metals in the soil indicated contamination from the effluent from the factories in the area. Plant sampled indicated the presence of higher level of $\mathrm{Pb}$ and $\mathrm{Cd}$ in the tissues of leaf and roots than that of the reference samples. CJASEM
\end{abstract}

http://dx.doi.org/10.4314/jasem.v20i3.17

Keywords: Pollution, discharge, effluent, irrigation, SAR, heavy metals.

Industrialization has transformed life on earth to levels previously unimaginable but has been of immense concern due to the wealth generated and the associated pollution as well as the threat to environment and human health. The environmental constraints posed by the natural boundaries of the ecosystems are very important in sharing the fruits of development on an equitable and sustainable basis. Exploitation of one resource has a direct impact on the other. But this factor was never considered in most of the earlier development initiatives in Nigeria particularly in Ibadan, Oyo state vis-à-vis the development effort which could not achieve the goal of poverty alleviation of the people. Development activities thus implemented have resulted in serious negative impacts on adjacent areas due to the creation of imbalances in the existing environment.

Despite the effort of Nigeria Government in putting up pollution abatement measures and to treat their waste, particularly waste waters before discharging into the nation's sustainable development through legal framework, over $80 \%$ of industries still discharge solid waste, liquid effluent and gaseous emission directly into the environment without treatment (Federal Ministry of Water Resources, 1994). This scenario points to a growing problem of industrial pollution that threatens the health of the ecosystem (water sources) and in particular agricultural activities. This is more so that moisture remains the most critical agrometeorological factor for crop production in the tropics (Krammer, 1963).

In the study area, one major persistent problem for agriculture is that of water supply which is manifested by the seasonal and variability of rainfall. Rainfall variability in the area is not limited to seasonal fluctuations but also includes year to year variability in the onset, cessation and duration of the rains which are also characterized by dry spells of unpredictable magnitude. Hence, adoption of irrigation from surface source becomes imperative during the short fall in rainfall as means of improved crops production (Olasantan, 2007) in particular vegetables. However, industrial pollution has deteriorating effect on the water quality used for irrigation. The discharge untreated effluents into the Eleshin stream resulted in a perpetual stench and a permanent brown (dirty) coloration of the water. A work through vegetable farms of Osun Abolowojaiye, Majawe and Papa Adogba village revealed some peculiar strains on the morphological growth of some horticultural crops which were probably due to the dissolved salts in present in the irrigation water resulting from industrial effluent discharge into the upstream surrounding water. Research into analytical assessment of surface 
water have been extensive in all the eco-climatic zones of Nigeria but in contrast, research endeavour in assessment of irrigation water quality is not only small but restricted to the savanna region. Notable examples are those of Osibanjo (1990), Awomeso et al. (2009), Oladiji et al. (2004). The aim of this study was to assess the impact of impact of upstream industrial effluents discharge in streams and ground water used for irrigation water quality, as well as the vegetation in Nigeria.

\section{MATERIALS AND METHODS}

Study area: Ibadan $\left(7^{\circ} 54^{\prime} \mathrm{N}, 3^{\circ} 54^{\prime} \mathrm{E}\right)$ in Oyo State, Southwestern Nigeria covers an area extent of $3,080 \mathrm{~km}^{2}$. The Alakia area of the city (Fig. 1A), comprising of three fast growing communities of Papa Adogba, Majawe and Oshun Abolowojaiye are located on the outskirts of the metropolis. The area is characterized by a tropical climate with distinct wet and dry seasons with bimodal rainfall pattern and mean annual air temperature of about $30^{\circ} \mathrm{C}$. The annual rainfall totals ranges between 1200 and $1400 \mathrm{~mm}$. According to "Gbadegesin and Olabode, 1999", the soils of the Ibadan metropolis belong to the major soil group of ferruginous tropical soils and the soils of the Ibadan region can be further classified into four soil associations. All the four soil associations can be used for producing food crops such as cassava and maize but only one of these, the Egbeda soil association can be profitably used for producing tree crops such as cocoa and kola.

The inhabitant's livelihood strategies include agriculture, short and long-distance trading, and a variety of urban occupations. Traditionally, very little farming went on within the limits of Ibadan while the belt surrounding the town was used for cultivation of crops. The town land was used primarily for residential and public buildings, markets, shrine and paths (Fig. 1B). Only a small portion of the city land is used for production of vegetable. However, there are lots of pre-urban area within Ibadan were farming is largely the inhabitants occupation. Crops such as yam, sorghum, maize, cassava, cocoyam, Mellon, okra, tomato, pepper and vegetables are the major crops grown in the area. Farming in this region is almost entirely reliant on 6 to 7 months of rainfall and augmented by small scale irrigation in particular for vegetables.

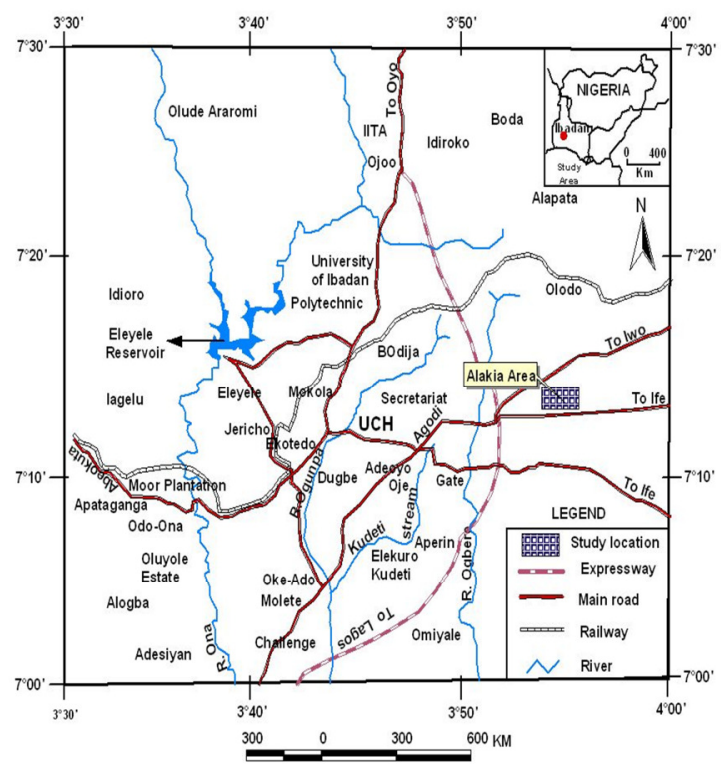

A: Topographical map of Ibadan

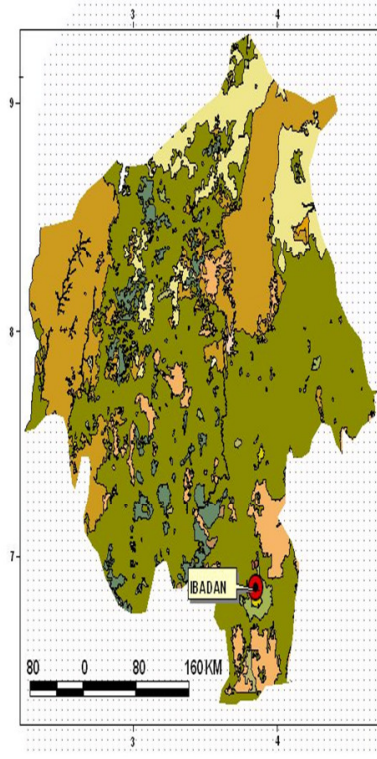

B: Land-use map of Ibadan

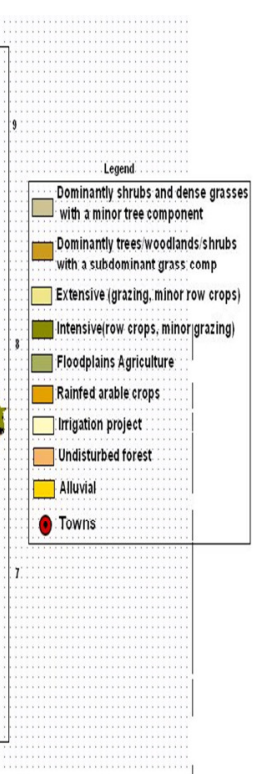

Fig. 1: Map showing physical map of Ibadan in Oyo State, Southwestern Niger
Study location layout: Three communities, namely Papa Adogba, Majawe and Oshun Abolowojaiye in Ibadan were visited in December, 2012 during the dry season. Figure 2 illustrated the site of industries in relation to the ecology and sampling points. The brewery industry treatment plant is located at the lower end of the shaded area at point "A". the effluent of the treatment plant are discharged through two channels constructed to pass under the factory fence leading to a nearby Elesin stream. The water from the upstream (B1) appeared colourless, while the water discharged from "A" was cream colour. The upper 
stream flows slowly, but from the point of effluent discharge to the downstream, the water flow rapidly indicates constant discharge from the factory. The extent of assessment was about $2 \mathrm{~km}$ from point "A" along the downstream area.

Sample collections: Water sample from the Elesin stream were taken upstream, marked "B1" in Figure 2. Samplings were also taken at point "A", where the effluent discharge from the breweries joins the body of the stream. Well water located about 10 and 50m away from polluted stream in the downstream direction was also sampled. Samples was equally made at the point of discharge directly from factory, $5 \mathrm{~m}$ away from the 1 . discharge point and at two points each in the Osun and Papa Adoga communities. The sample locations are as shown in figure 2. Most of the wells dug close to2. stream were abandoned due to odor, taste and the harmful effects of the well water for human consumption but used for irrigation. The odour of the 3 . polluted water was highly unpleasant and noxious.

Eight soil composite samples were taken in two depth ${ }^{5}$ ranges of $0-20$ and $20-40 \mathrm{~cm}$, and at random at 3 and $100 \mathrm{~m}$ to discharge points $5 \mathrm{~m}$ on either side of the stream bank on the land of Osun and Papa Adogba community. Soil samples were taken at the upstream at Isebo communities to serve as control. The salt constituents of samples were analyzed following the standard methods (APHA 1989: Suess 1982).

Nine plant samples of some of the existing foods, fruits, vegetable crops cultivated on the inland valleys were taken for lab analysis and analyzed for some nutrient contents.

Irrigation water quality criteria: The following categories were used to describe irrigation effects on crop production and soil quality:

Sodium hazard - relative proportion of sodium $\left(\mathrm{Na}^{+}\right)$ to calcium $\left(\mathrm{Ca}^{2+}\right)$ and magnesium $\left(\mathrm{Mg}^{2+}\right)$ ions. This was expressed as sodium adsorption ratio (SAR)

$$
\mathrm{SAR}=\frac{N a^{+}}{\sqrt{\frac{C a^{2+}+M g^{2+}}{2}}}
$$

$\mathrm{pH}$

4. Specific ions: chloride $(\mathrm{Cl})$ and nitrate $\left(\mathrm{NO}_{3}\right)$.

5. Heavy metals

Analytical procedure" The analytical procedures used for the chemical and physico-chemical parameters are as presented in table below:

\begin{tabular}{ll}
\hline Parameters & Analytical methods \\
\hline $\mathrm{Na}$ & Flame photometer (Jenway PFP 7) \\
$\mathrm{Ca}$ & EDTA Titrimetric Method(method 8049) \\
$\mathrm{Mg}$ & SpectroVphotometry using HACH DR/2400 \\
$\mathrm{pH}$ & Potentiometric, Using pH meter \\
$\mathrm{Cl}$ & Mercuric Nitrate Method \\
$\mathrm{NO}_{3}$ & Spectrophotometry using HACH DR/2400 (method 8171) \\
$\mathrm{Pb}$ & Spectrophotometry using AAS- BUCK model 200A \\
$\mathrm{Cd}$ & Spectrophotometry using AAS- BUCK model 200A \\
$\mathrm{Cu}$ & Spectrophotometry using AAS- BUCK model 200A \\
$\mathrm{Zn}$ & Spectrophotometry using AAS-BUCK model 200A \\
\hline
\end{tabular}

\section{RESULTS AND DISCUSSION}

Water: From the irrigation water quality analysis results obtained from the field sampling in the communities presented in figure 2 , the $\mathrm{pH}$ was mostly acidic (5.35-6.5) and this does not conform with the permissible range of 6.5-8.5 (FAO, 1985) and those of the control samples. It was observed that only the control samples were within the permissible limits. The samples showed $\mathrm{pH}$ below the lower limit of 6.5 with the exception of that from Papa Adogba well
$(\mathrm{pH}=6.65)$, which contained high Sodium Adsorption ratio $(\mathrm{SAR}=11.1)$. High $\mathrm{pH}$ often caused by bicarbonate $\left(\mathrm{HCO}_{3}^{-}\right)$and carbonate $\left(\mathrm{CO}_{3}{ }^{2-}\right)$ concentration known as alkalinity. High carbonates cause high SAR which is as a result of calcium and magnesium ions forming insoluble minerals leaving sodium as the dominant ion in solution. The well water had a $\mathrm{pH}$ ranging from $6.0-6.5$, while the stream water ranged from $5.6-5.8$. In all cases the stream water had a $\mathrm{pH}<6$. 

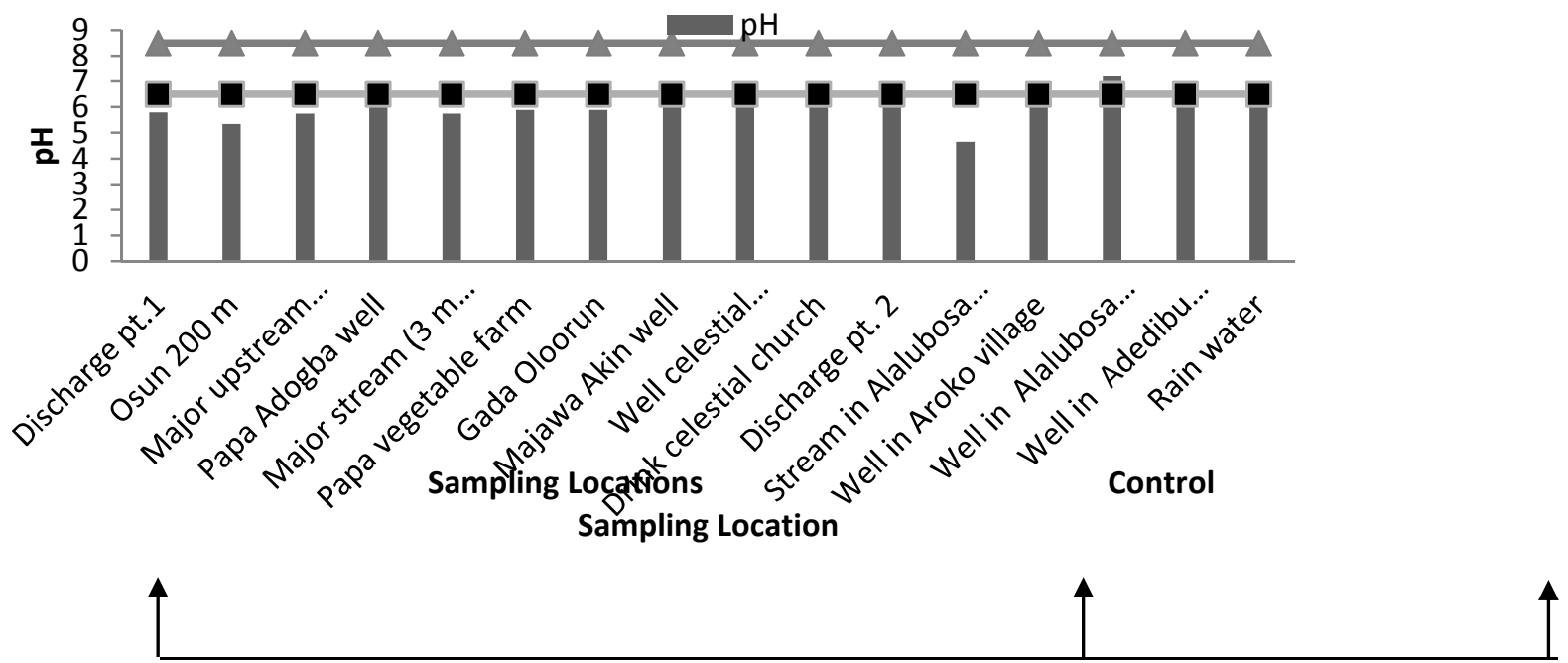

Fig. 2: pH range of irrigation water at the sampling points and the control points

Figure 3 shows the sodium adsorption ratio of the irrigation water quality of the samples in the affected communities. The SAR quantifies the proportion of sodium $\left(\mathrm{Na}^{+}\right)$to calcium $\left(\mathrm{Ca}^{2+}\right)$ and magnesium $\left(\mathrm{Mg}^{2+}\right)$ ions in a sample. The SAR was mostly low sodium in water (0.46-7.06) and this does conform with the permissible level of $<9$ (FAO, 1985) and those of the control samples. The samples showed SAR of $<9$ with exception of that from the Papa Adogba well $(\mathrm{SAR}=11.1)$, which contained high $\mathrm{pH}(\mathrm{pH}=6.65)$ and high Chloride ion $\left(\mathrm{Cl}^{-}\right.$of $147.6 \mathrm{ppm})$ and Nitrate $\left(\mathrm{NO}_{3}{ }^{2-}\right.$ of $\left.2.04 \mathrm{ppm}\right)$ concentration as shown in figure 4. The well water had SAR ranging from $0.77-7.06$, while the stream water ranged from $0.54-11.1$.

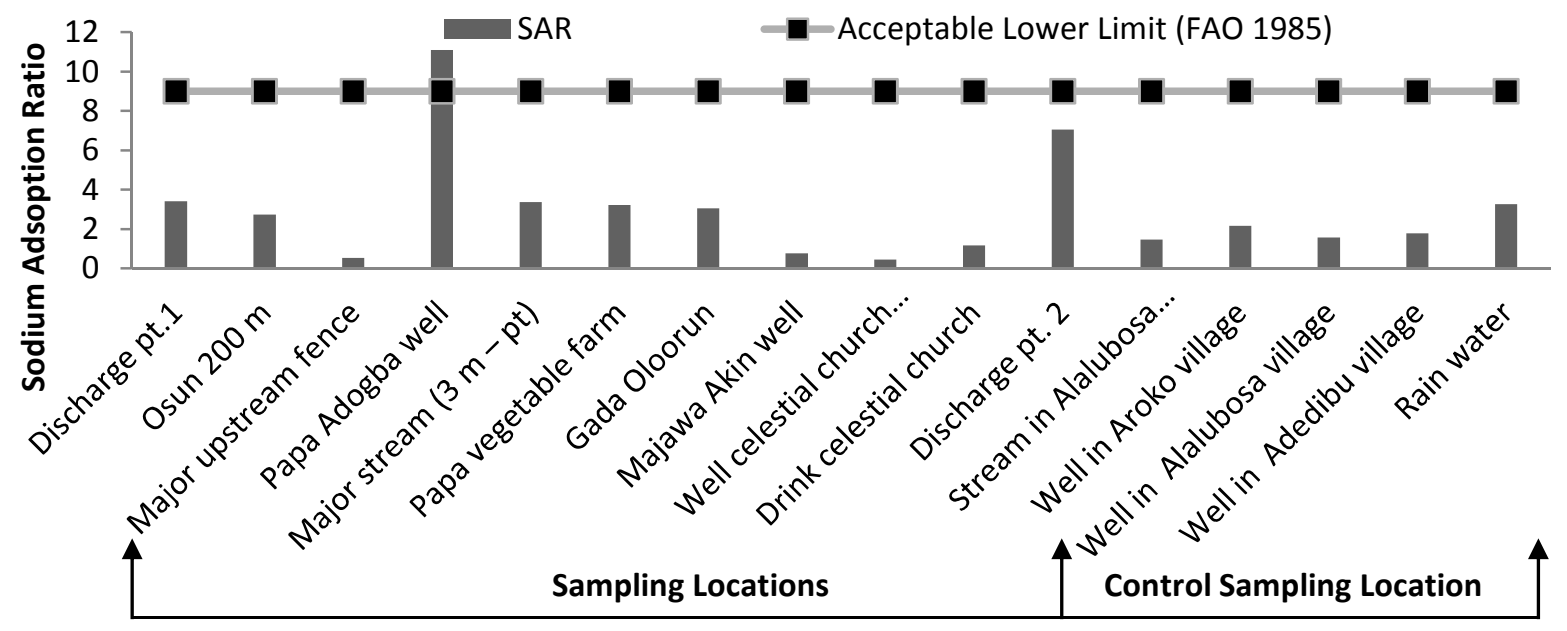

Fig. 3: Sodium adsorption ratio of irrigation water at the sampling points and the control points

Although chloride is essential to plants in very low amounts, it can cause toxicity to sensitive crops at high concentration. Figure 4 shows that chlorine considerably high (ranging from nil - $147.6 \mathrm{ppm}$ ) in the samples of wells water used for irrigation in the affected communities though lower than the FAO limit $(200 \mathrm{ppm})$ and the control samples wells at Aroko village and Alalubosa village (average of $3000 \mathrm{ppm}$ ). The highest was observed at Papa Adogba well. Like in sodium, high chloride concentrations cause more problem of leaf burning as a result of direct contact of irrigation water with leaf surface particularly when applied with sprinkler irrigation. Furthermore, water high in nitrogen can cause quality problems in some crops and excessive vegetative growth in some vegetables. However, these problems can usually be overcome by good fertilizer and irrigation management. Regardless of the crop, nitrate should be 
credited towards the fertilizer rate especially when the concentrations exceed $45 \mathrm{ppm} \mathrm{NO}_{3}^{-}$. In all the samples collected at the study area, the $\mathrm{NO}_{3}{ }^{-}$are considerably low (ranging from $2.04-3.32 \mathrm{ppm}$ ) compared the
FAO limit (> 10) of the control samples (ranging from $4.65-7.20 \mathrm{ppm}$ ) except at Papa vegetable farm and Gada Oloorun having an average of $11.0 \mathrm{ppm}$.

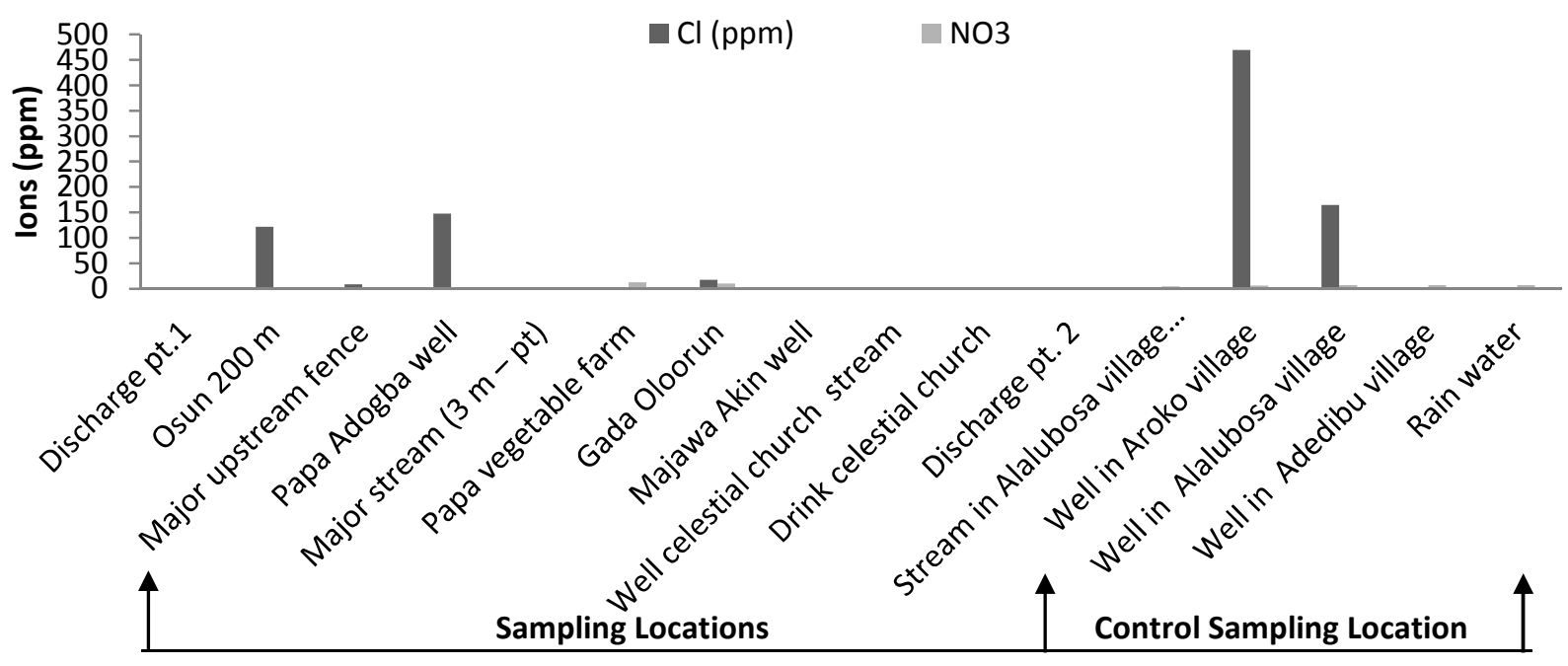

Fig. 4: Anions concentration of irrigation water at the sampling points and the control points

Figure 5 shows the heavy metal concentration in irrigation water quality of the samples in the affected communities. The level of heavy metals, such as $\mathrm{Cd}$ and $\mathrm{Zn}$ were high in most of the irrigation water sampled than the FAO specified limits of $0.01 \mathrm{ppm}$ and $2.00 \mathrm{ppm}$ respectively. However, the $\mathrm{Pb}$ and $\mathrm{Cu}$ were within the specified FAO limits. The high level of metal content observed is due to low $\mathrm{pH}$ values recorded for the samples. This is because the acidic medium indicated by low $\mathrm{pH}$ generally leads to the release of metals, which are otherwise immobile. Most of the irrigation water samples from wells contained metals concentration lower than the irrigation water from streams. This is expected because the higher the $\mathrm{pH}$ values, the lower the release of metals.

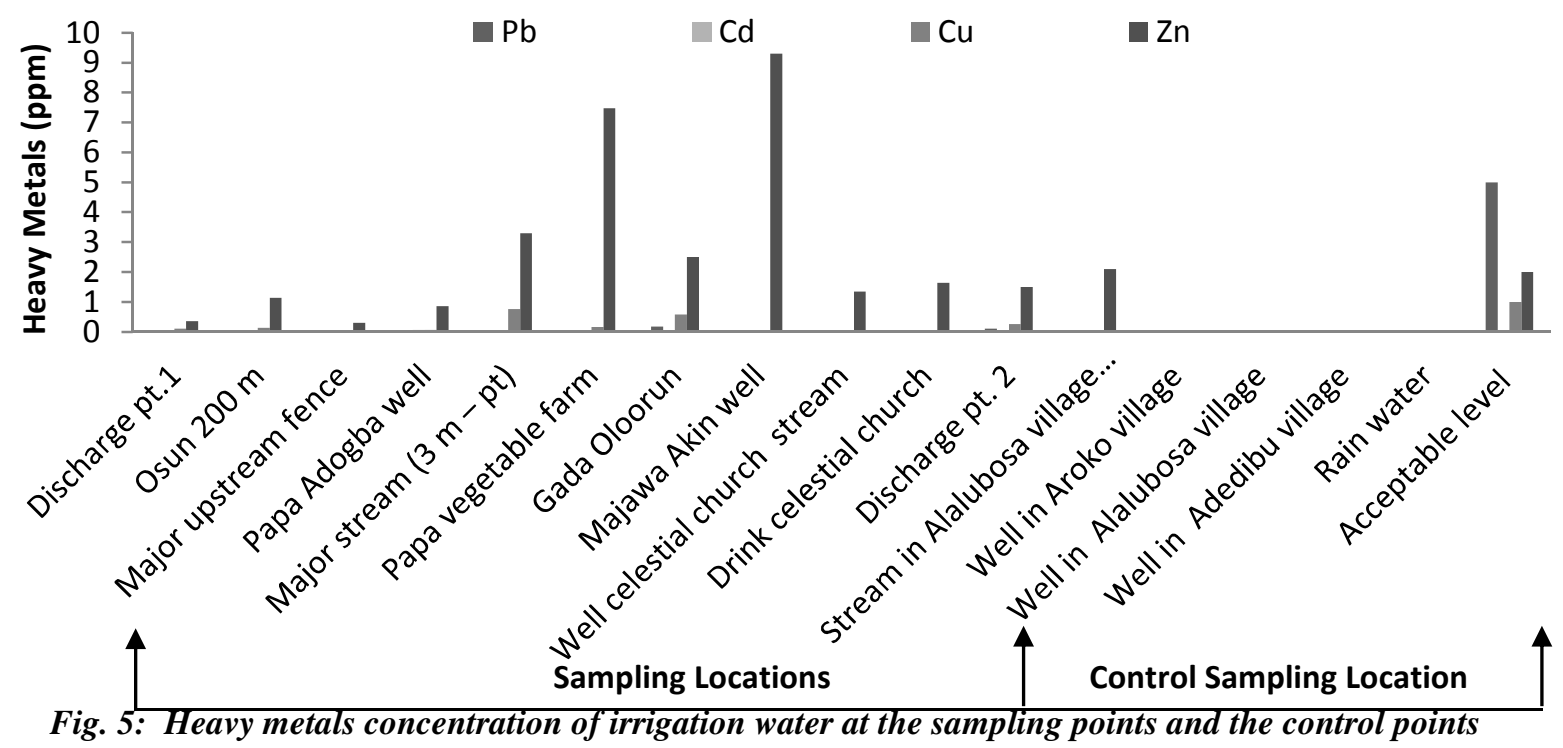

The Isebo upper stream serves as control or reference point. The stream samples here contained higher concentration of $\mathrm{Cd}$ and $\mathrm{Cu}$ than samples irrigation water from Elesin stream taken from the downstream area. About $10 \mathrm{~m}$ upstream before the Elesin stream, water mixes with the discharge water from the breweries, effluents and all the heavy metals concentration are higher than the values at discharge point ' $\mathrm{A}$ '. This is indicative of possible pollution from the brewery effluent. It is important to note that 
continuous intake of this irrigation water may be harmful to most crop. The irrigation water from both the wells and stream in the area contained higher concentration of $\mathrm{Cd}$ (ranging from $0.01-0.06 \mathrm{ppm}$ ) and $\mathrm{Zn}$ (ranging from $0.30-9.30 \mathrm{ppm}$ ). It is therefore not desirable for agricultural production.

Soil "The average pH of the soil samples was about 5, and it ranges from $4.75-5.35$, indicating strong acidity with $\mathrm{pH}$ below the lower limit of 6.5 as shown in figure 6. High $\mathrm{pH}$ in soil as in the irrigation water is associated with bicarbonate $\left(\mathrm{HCO}_{3}{ }^{-}\right)$and carbonate $\left(\mathrm{CO}_{3}{ }^{2-}\right)$ concentration leading to high SAR. Figure 7 shows the Sodium adsorption ratio of soil at the sampling locations, it was observed that the soil at
Isebo 0-20 cm has highest SAR (5.68). The high SAR at Isebo $0-20 \mathrm{~cm}$ may be as a result of soil texture, the organic matter and the management impact of irrigation water on soil. Sodium in irrigation water and soil is known to cause toxicity problems for some cultivated crop in the location. The soil at 3 and $100 \mathrm{~m}$ from the point of effluent discharge downstream contained high concentrations of heavy metals such as $\mathrm{Pb}(10.65 \mathrm{ppm}), \mathrm{Cu}(13.8 \mathrm{ppm})$ and $\mathrm{Zn}(65 \mathrm{ppm})$ as compared with the reference soil (Isabo samples) with $\mathrm{Pb}$ (4.62 ppm), $\mathrm{Cu}$ (3.10) and $\mathrm{Zn}(3.70 \mathrm{ppm})$ as observed in figure 8 . The behavior confirms the high mobility of heavy metal actions under acid conditions that will lead to stunted growth, development and subsequent poor yield of crop.

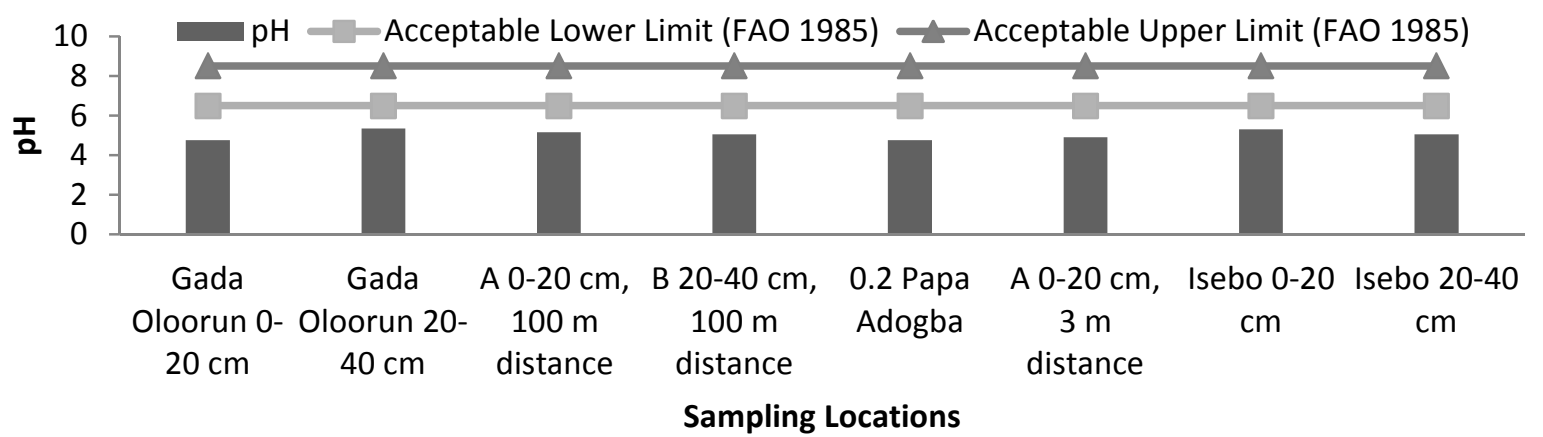

Fig. 6: $\quad$ pH range of soil at the sampling locations

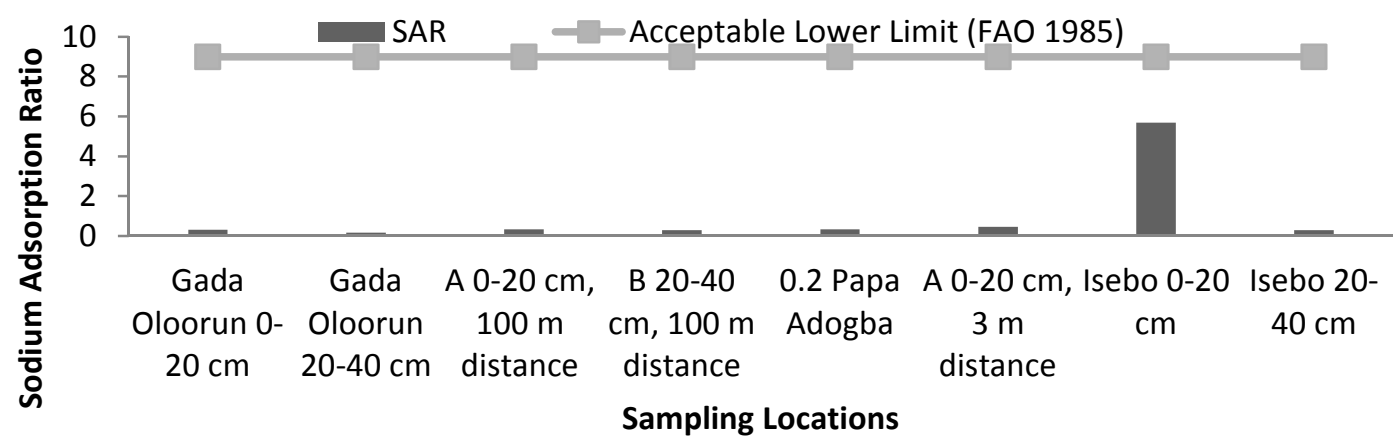

Fig. 7: Sodium adsorption ratio of soil at the sampling locations 


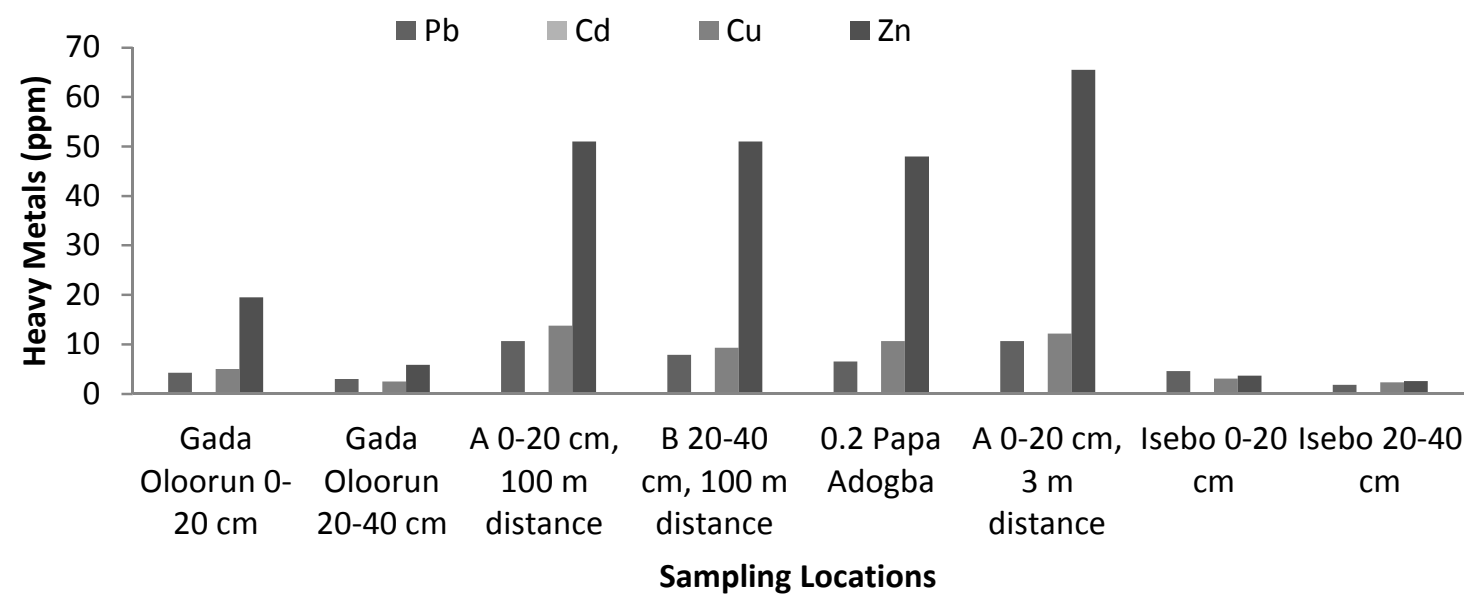

Fig. 8: Heavy metals concentration of soil at the sampling locations

Plant: Figure 9 shows the heavy metals in randomly selected plant tissues of various crops at the sampling locations. $\mathrm{Pb}$ and $\mathrm{Cd}$ were not detected in the plant and root tissue partly as a result of selective absorption of heavy metals. The concentration of $\mathrm{Cu}$ and $\mathrm{Zn}$ ranged from moderate to high in the tissues the highest level of $\mathrm{Cu}$ and $\mathrm{Zn}$ were found in lettuce leaf ( $35 \mathrm{ppm}$ and $745 \mathrm{ppm}$ respectively) and root (17.5 ppm and 322.5 ppm respectively). It was followed by Maize and
Banana grown in vegetable farm. The accumulation of these heavy metals may be toxic to man and animals. Furthermore, the concentration of $\mathrm{Ca}$ and $\mathrm{Na}$ were low for all the randomly selected plant tissues of various crops. The highest as in the heavy metals in the tissues were found in lettuce leaf $(1.01 \mathrm{ppm}$ and $2.78 \mathrm{ppm}$ respectively) and root (1.10 ppm and $1.24 \mathrm{ppm}$ respectively). It was followed by cocoa plant at Majawe discharge point as shown in figure 10.

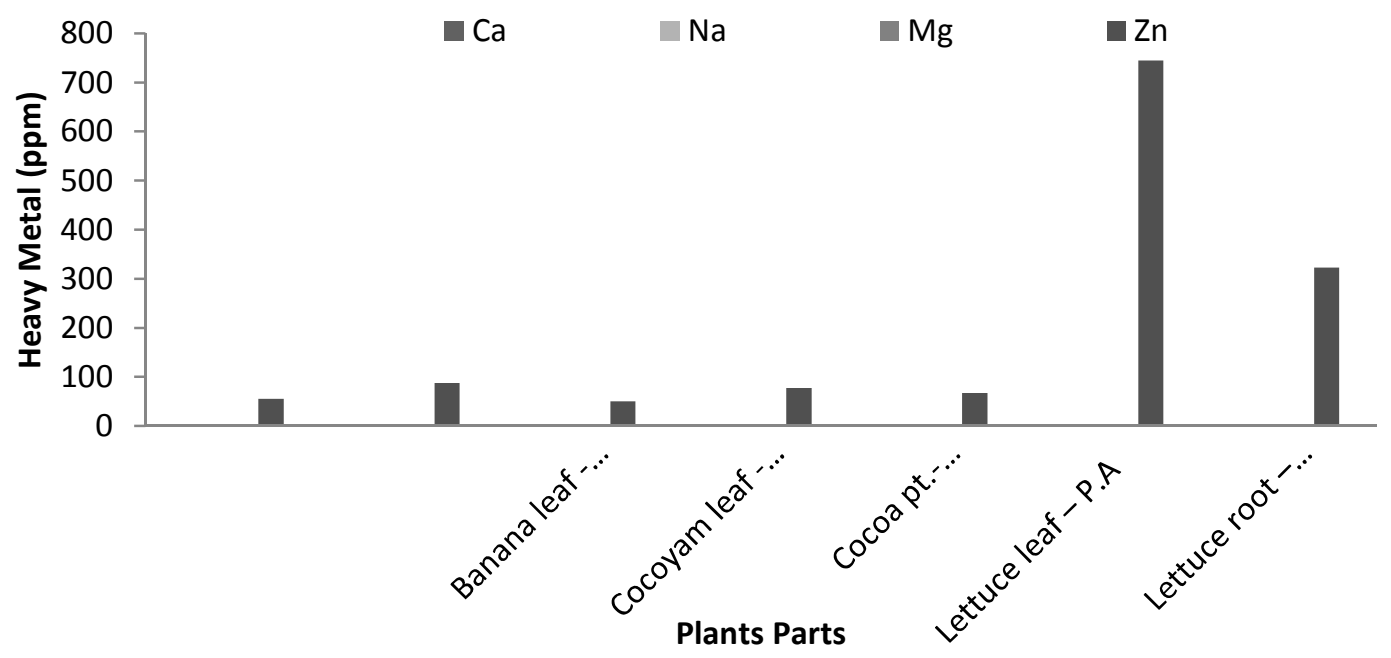

Fig. 9: Heavy metals concentration in some selected plant tissue at the sampling locations 


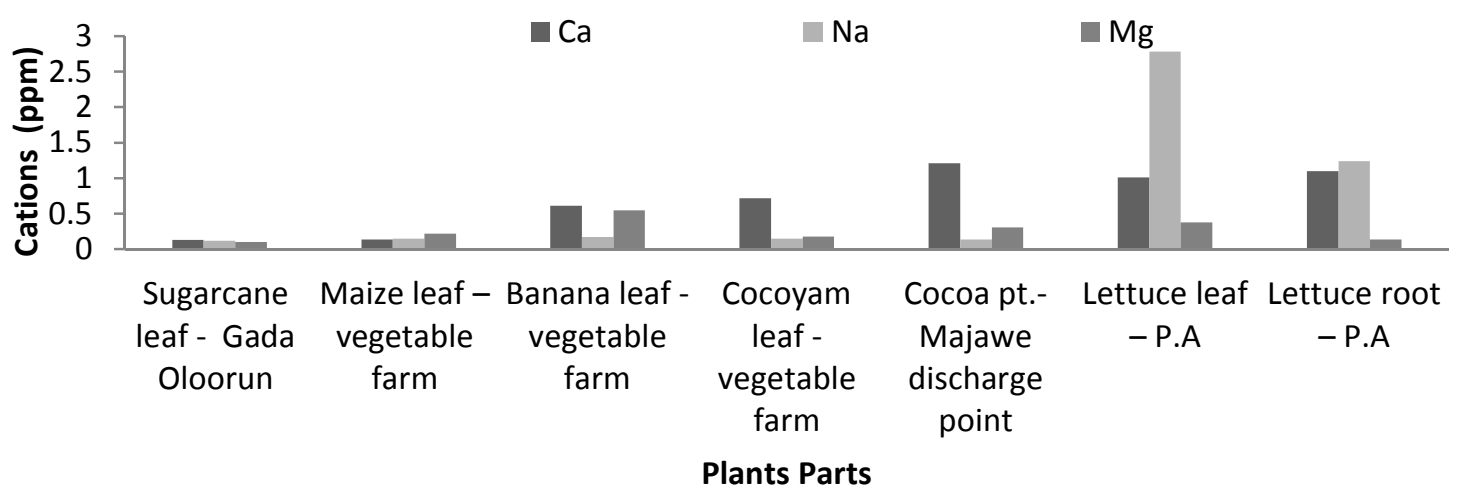

Fig. 10: some cation concentration in some selected plant tissue at the sampling locations

Conclusion: The study revealed that the Eleshin stream and the surrounding ground water has low sodium hazard thereby making it fit for irrigation. However, both the stream and the surrounding well are acidic, thus enhancing leaching and corrosive tendencies of the irrigation water. The high the level of heavy metals in the soil indicated contamination from the effluent from the factories in the area, some which are washed by runoff and infiltrate into the soil to join the groundwater (well) in the location. Though, some of the plant samples do not indicate the presence of $\mathrm{Pb}$ and $\mathrm{Cd}$ in the tissues of leaf and roots, an appreciable amount of sampled plant indicated the presence of heavy metals higher than that of the reference samples.

\section{REFERENCES}

APHA (1989). Standard methods for examination of water and wastewater, $17^{\text {th }}$ edition. New York. American Public Health Association (APHA); American Water Works Association (AWWA), and Water Pollution Control Federation (WPCF) (prepared and published jointly).

Awomeso, JA; Ufoegbune, GC; Oluwasanya, GO; Ademola - Aremu, OO (2009). Impact of industrial effluents on water, soils and plants in Alakia industrial area of Ibadan, South West Nigeria. Toxicological and Environmental Chemistry. Vol. 91(1):2-15. Taylor \& Francis.

Food and Agriculture Organization (1985). Guidelines of interpretation of water quality of irrigation water. Paper No 29 Rev., Rome

Federal Ministry of Water Resources (1994). The study of the National Water Resources

Master plan under Japan International Cooperation Agency (JICA). Abuja: Federal Ministry of Water Resources.
Gbadegesin, A; Olabode M (1999). The Soils of the Ibadan Metropolis: Nature and Characteristics. Land Contamination \& Reclamation. 7 (3): 209217.

Krammer, PJ (1963). Water stress and plant growth. Agronomy Journal, 5: 31-35

Oladiji, AT; Adeyemi, O; Abiola, OO (2004). Toxicological evaluation of the surface water

of Amilegbe River. Nigeria society for Experimental Biology. MS/NO BKM 12004/015.

Olasantan, FO (2007). Effect of population density and sowing date of pumpkin on soil hydrothermal regime, weed control and crop growth in a yam pumpkin intercrop.Experimental Agriculture 43: 365-380.

Osinbanjo, OO (1990). Industrial pollution and land degradation. Paper delivered at IART,

December 4 - 6, 1990, in Moore Plantation, Ibadan, Nigeria.

Suess, MJ (1982). Examination of water for pollution control, vols. 1, 2. United Kingdom: Pergamon Press. 